\title{
Enzyme evolution in Rhodobacter sphaeroides: selection of a mutant expressing a new galactitol dehydrogenase and biochemical characterization of the enzyme
}

\author{
Karl-Heinz Schneider, ${ }^{1}$ Gregor Jäkel, ${ }^{1}$ Ralf Hoffmann ${ }^{2}$ \\ and Friedrich Giffhorn ${ }^{1}$
}

Lehrstuhl für Angewandte Mikrobiologie ${ }^{1}$ and Fachrichtung 12.4 Biochemie, 2Universităt des Saarlandes, Postfach 1511 50, D-66041 Saarbrücken, Germany
Author for correspondence: Friedrich Giffhorn. Tel: +49681302 3444. Fax: +496813024360.

A gain of function mutant of Rhodobacter sphaeroides Si4, capable of growing on galactitol, was isolated from a chemostat culture. Continuous cultivation was performed for $54 \mathrm{~d}$ with a limiting concentration (1 $\mathrm{mM}$ ) of the substrate D-glucitol and an excess $(20 \mathrm{mM})$ of the non-metabolizable galactitol. The mutant strain, $R$. sphaeroides $D$, grew in galactitol minimal medium with a growth rate of $0.11 \mathrm{~h}^{-1}\left(t_{d}=6.3 \mathrm{~h}\right)$. In crude extracts of $R$. sphaeroides $D$, a specific galactitol dehydrogenase (GDH) activity of $380 \mathrm{mU} \mathrm{mg}^{-1}$ was found, while the wild-type strain exhibited GDH activities lower than $50 \mathrm{mU} \mathrm{mg}^{-1}$ when grown on different polyols. Unlike mannitol, sorbitol or ribitol dehydrogenase from the wild-type strain, the new GDH was expressed constitutively. To study whether it was a newly evolved enzyme or an improved side activity of one of the pre-existing polyol dehydrogenases, GDH was purified to apparent homogeneity by ammonium sulfate precipitation and chromatography on Phenyl-Sepharose, Q-Sepharose, Matrex Gel Red-A and Mono-Q. The relative molecular mass $\left(M_{r}\right)$ of the native GDH was 110000 . SDSPAGE resulted in one single band that represented a polypeptide with a $M_{r}$ of 28000 , indicating that the native protein is a tetramer. The isoelectric point of GDH was determined to be pH 4.2. The enzyme was specific for NAD+ but catalysed the oxidation of different sugar alcohols as well as different diols and secondary alcohols. The apparent $K_{m}$ values were : galactitol, $240 \mathrm{mM}$; Dthreitol, $85 \mathrm{mM}$; 1,2-hexandiol, $0.2 \mathrm{mM}$; NAD+, $12 \mu \mathrm{M}$; L-erythrulose, $144 \mathrm{mM}$; acetoin, $62 \mathrm{mM}$; dihydroxyacetone, $48 \mathrm{mM}$; and NADH, $4 \mu \mathrm{M}$. GDH activity was strictly dependent on the presence of divalent cations. The properties of GDH are different to any of the three polyol dehydrogenases from $R$. sphaeroides Si4. In addition, comparison of the $\mathbf{N}$-terminal amino acid sequence of the isolated GDH with the $\mathbf{N}$-terminal sequence of the other three polyol dehydrogenases clearly demonstrates that GDH is an additional enzyme, so far unrecognized in the wild-type strain.

Keywords: Rbodobacter sphaeroides, polyol metabolism, galactitol dehydrogenase, chemostat, enzyme evolution

\section{INTRODUCTION}

The ability of bacteria to adapt to novel nutritional conditions is well known (Lerner et al., 1964; Hegeman \&

Abbreviations: GDH, galactitol dehydrogenase; $M D H$, mannitol dehydrogenase; RDH, ribitol dehydrogenase; SDH, sorbitol dehydrogenase.

Dedicated to Professor Dr Gerhard Gottschalk on the occasion of his 60th birthday.
Rosenberg, 1970; Hartley et al., 1972), and mutants with improved or new metabolic capabilities have been isolated readily from cultures grown under selective pressure in a chemostat (Dykhuizen \& Hartl, 1983). New metabolic capabilities may arise by regulatory mutations resulting in the overproduction of an enzyme with a marginal specificity for the new substrate (LeBlanc \& Mortlock, 1971; Rigby et al., 1974; Chen et al., 1984) or by mutations in structural genes leading to altered or new substrate 
specificities of the respective enzymes (Hall, 1981 ; Doten \& Mortlock, 1984; Buchholz et al., 1988; Srinivasan et al., 1993; Lambert et al., 1994). Finally, cryptic genes may be expressed (Hall et al., 1983) which often results in the constitutive formation of the encoded enzyme (Szymona \& Doudoroff, 1960; Rode \& Giffhorn, 1982, 1983). Therefore, growth of bacteria in a chemostat in the presence of limiting concentrations of a utilizable substrate and excess of a non-utilizable but chemically related substrate can be used as a promising strategy for obtaining enzymes with new or favourably altered properties. In this respect polyol dehydrogenases have been shown to be model systems for studying experimental enzyme evolution. These enzymes are relatively unspecific and can be produced with elevated levels or altered in their specificities under conditions of selective pressure (Wu $e t$ al., 1968; Rigby et al., 1974; Wawzonek Thompson \& Krawiec, 1983; Doten \& Mortlock, 1984; Kyslik \& Dobisova, 1986; Buchholz et al., 1988). In view of developing applications of polyol dehydrogenases in synthetic carbohydrate chemistry (Drueckhammer et al., 1991; Schwartz et al., 1994; Mayers-Küntzer et al., 1994), the exploitation of new polyol dehydrogenases using the method of enzyme evolution seems to be a promising approach.

One objective of our studies is the phototrophic bacterium Rhodobacter sphaeroides Si4 which grows on a variety of polyols including D-mannitol, D-glucitol (sorbitol), Darabitol, ribitol and xylitol but does not grow on galactitol. The polyols are metabolized by NAD-linked dehydrogenation to the corresponding sugars by virtue of inducible mannitol dehydrogenase (MDH; EC 1.1.1.67) (Schneider \& Giffhorn, 1989), ribitol dehydrogenase (RDH; EC 1.1.1.56) (Kahle et al., 1992) and sorbitol dehydrogenase (SDH; EC 1.1.1.14) (Schauder et al., 1995). Although both SDH and MDH possess marginal specificities for galactitol, apparently the organism cannot take advantage of these activities for utilizing this carbon source for growth. Selective pressure on R. sphaeroides Si4 was established by simultaneous exposure of the organism to limiting amounts of the utilizable substrate D-glucitol in the presence of an excess of the non-metabolizable analogue galactitol. Here we report the selection of a galactitol-metabolizing mutant of R. sphaeroides $\mathrm{Si4}$, the characterization of a unique and newly expressed galactitol dehydrogenase (GDH) and its suitabilty for the synthesis of rare sugars from polyols.

\section{METHODS}

Organisms and growth conditions. The purple non-sulfur bacterium Rbodobacter sphaeroides strain Si4 (DSM 8371) is an isolate from this laboratory (Rode \& Giffhorn, 1983). R. spbaeroides $\mathrm{D}$ is a mutant of strain $\mathrm{Si} 4$ capable of growing on galactitol as sole source of carbon and energy. R. sphaeroides was grown heterotrophically at $30^{\circ} \mathrm{C}$. The medium for enzyme evolution contained the following components: D-glucitol, $1 \mathrm{mM}$; galactitol, $20 \mathrm{mM}$; $\mathrm{KH}_{2} \mathrm{PO}_{4}, 7.4 \mathrm{mM}$; $\mathrm{NH}_{4} \mathrm{Cl}, 9.4 \mathrm{mM}$; $\mathrm{MgSO}_{4} .7 \mathrm{H}_{2} \mathrm{O}, 1.6 \mathrm{mM} ; \mathrm{NaCl}, 6.8 \mathrm{mM} ; \mathrm{CaCl}_{2} .2 \mathrm{H}_{2} \mathrm{O}$, $0.34 \mathrm{mM} ; 10 \times$ trace element solution SL4 (Pfennig \& Lippert,
1966), $1.0 \mathrm{ml} \mathrm{l}^{-1} ; 10 \times$ vitamin solution (Rode \& Giffhorn, 1983), $1.0 \mathrm{ml} \mathrm{l}^{-1}$. The $\mathrm{pH}$ was adjusted to 6.8 with $\mathrm{NaOH}$. Batch cultivations of $\mathrm{R}$. sphaeroides $\mathrm{D}$ and $\mathrm{Si} 4$ were performed in the same minimal medium with the appropriate carbon source at a concentration of $10 \mathrm{mM}$.

Enzyme assays and protein determination. Polyol dehydrogenase activities were determined as described previously (Schneider \& Giffhorn, 1989). Protein concentrations were determined by the method of Goa (1953) with crystalline bovine serum albumin as standard.

Purification of GDH. Wet cells (61 g) were suspended in $180 \mathrm{ml}$ Bistris/ $\mathrm{HCl}$ buffer $\left(20 \mathrm{mM}, \mathrm{pH} 6.5+1 \mathrm{mM} \mathrm{MgCl}_{2}\right)$ and $10 \mathrm{mg}$ DNase I was added. Cells were disintegrated by two passages through a French press at $11000 \mathrm{~N} \mathrm{~cm}^{-2}$. Subsequently the cell debris was removed by centrifugation at $4{ }^{\circ} \mathrm{C}$ and $53000 \mathrm{~g}$ for $30 \mathrm{~min}$.

Unless otherwise specified all following operations were carried out at $4{ }^{\circ} \mathrm{C}$.

Step 1. During stirring on ice, saturated $\left(\mathrm{NH}_{4}\right)_{2} \mathrm{SO}_{4}$ solution was added dropwise to the crude extract until $30 \%$ saturation was reached. The precipitated proteins were removed by centrifugation at $30000 \mathrm{~g}$ for $30 \mathrm{~min}$. The supernatant was filtered through a nitrocellulose $0.45 \mu \mathrm{m}$ pore size filter.

Step 2. The protein solution from step 1 was applied to a C 16/20 Phenyl Sepharose column (Pharmacia), containing $23 \mathrm{ml}$ of the resin, equilibrated with Bistris buffer $(20 \mathrm{mM}$, $\left.\mathrm{pH} 6.5+1 \mathrm{mM} \mathrm{MgCl})_{2}\right)$ with $25 \%\left(\mathrm{NH}_{4}\right)_{2} \mathrm{SO}_{4}$ saturation. The proteins were eluted with a linear $\left(\mathrm{NH}_{4}\right)_{2} \mathrm{SO}_{4}$ gradient $(25-0 \%$ saturation) in $250 \mathrm{ml}$ Bistris buffer (20 mM, pH 6.5+1 mM $\mathrm{MgCl}_{2}$ ) and $7 \mathrm{ml}$ fractions were collected. Fractions containing high GDH activities were pooled and dialysed against Bistris/ $\mathrm{HCl}$ buffer (20 mM, pH 6.5+1 $\mathrm{mM} \mathrm{MgCl}_{2}$ ).

Step 3. The dialysed enzyme solution was applied to a $\mathrm{XK}$ $50 / 30$ Q-Sepharose column with a bed volume of $80 \mathrm{ml}$, equilibrated with Bistris/ $\mathrm{HCl}$ buffer $(20 \mathrm{mM}, \mathrm{pH} 6.5+1 \mathrm{mM}$ $\mathrm{MgCl}_{2}$ ). The enzyme was eluted with a linear $\mathrm{NaCl}$ gradient $(0.1-0.4 \mathrm{M})$ in $480 \mathrm{ml}$ Bistris/ $\mathrm{HCl}$ buffer and $7 \mathrm{ml}$ fractions were collected. Fractions containing high enzyme activity were pooled and dialysed against Tris $/ \mathrm{HCl}$ buffer $(20 \mathrm{mM}$, $\mathrm{pH} 7 \cdot 5+1 \mathrm{mM} \mathrm{MgCl} 2+0 \cdot 1 \mathrm{M} \mathrm{KCl})$.

Step 4. The dialysed enzyme solution was applied to a $C 26 / 40$ Matrex Gel Red A affinity chromatography column with a bed volume of $42 \mathrm{ml}$, equilibrated with Tris/ $\mathrm{HCl}$ buffer $(20 \mathrm{mM}$, $\left.\mathrm{pH} 7 \cdot 5+1 \mathrm{mM} \mathrm{MgCl}_{2}+0 \cdot 1 \mathrm{M} \mathrm{KCl}\right)$. The enzyme was eluted with a linear $\mathrm{KCl}$ gradient $(0 \cdot 1-0.5 \mathrm{M})$ in $420 \mathrm{ml}$ Tris $/ \mathrm{HCl}$ buffer and $5 \mathrm{ml}$ fractions were collected. Fractions containing high GDH activity were pooled and concentrated by ultrafiltration through a YM 10 membrane (Amicon) to a volume of $2 \mathrm{ml}$ and dialysed against Tris $/ \mathrm{HCl}$ buffer $(20 \mathrm{mM}$, $\mathrm{pH} 8 \cdot 0+1 \mathrm{mM} \mathrm{MgCl}_{2}$ ).

Step 5. The enzyme preparation of step 4 was further purified by FPLC anion exchange chromatography on Mono-Q. The enzyme solution was applied to a Mono $Q$ HR 5/5 column equilibrated with Tris/HCl buffer $(20 \mathrm{mM}, \mathrm{pH} 8 \cdot 0+1 \mathrm{mM}$ $\left.\mathrm{MgCl}_{2}+0.1 \mathrm{M} \mathrm{NaCl}\right)$. The enzyme was eluted at a flow rate of $1 \mathrm{ml} \mathrm{min}{ }^{-1}$ with a linear $\mathrm{NaCl}$ gradient $(0.1-0.5 \mathrm{M})$ in $20 \mathrm{ml}$ Tris $/ \mathrm{HCl}$ buffer. Fractions of $0.5 \mathrm{ml}$ were collected at a flow rate of $1 \mathrm{ml} \mathrm{min}$. Fractions containing GDH activity were pooled.

Gel electrophoresis. Analytical PAGE was carried out in 10\% $(\mathrm{w} / \mathrm{v})$ slab gels using the Tris-Glycine buffer system (Davis, 1964). The gels were run at a current of $20 \mathrm{~mA}$. Proteins were 
visualized by silver staining (Merril et al., 1981). For activity staining of GDH, the gels were incubated for $5 \mathrm{~min}$ in a staining solution containing the following components in a final volume of $10 \mathrm{ml}: 0.2 \mathrm{M}$ Tris $/ \mathrm{HCl}(\mathrm{pH} 9 \cdot 0), 5 \mathrm{ml} ; 90 \mathrm{mM} \mathrm{NAD} \mathrm{NA}^{+}$ solution, $100 \mu \mathrm{l}$; nitro-blue tetrazolium chloride $\left(10 \mathrm{mg} \mathrm{ml}^{-1}\right)$, $100 \mu \mathrm{l} ; 5$-methylphenazonium methylsulfate $\left(1 \mathrm{mg} \mathrm{ml}^{-1}\right)$, $100 \mu$, galactitol solution $(0 \cdot 2 \mathrm{M}), 3 \mathrm{ml}$.

SDS-PAGE was performed in 15\% slab gels (Laemmli, 1970). The gels were run at a current of $10 \mathrm{~mA}$ per gel. For molecular mass determination of protein subunits, glutamate dehydrogenase $\left(M_{\mathrm{r}} 55600\right)$, aldolase (39200), triose-phosphate isomerase (26000), trypsin inhibitor (20100) and lysozyme (14300) were used as standards.

Linear polyacrylamide gradient gels $(4-20 \%, w / v)$ were run for $16 \mathrm{~h}$ at $150 \mathrm{~V}$ and subsequently at $200 \mathrm{~V}$ for $6 \mathrm{~h}$ (Anderson et al., 1972).

Determination of the isoelectric point. Isoelectric focussing was performed in polyacrylamide gels $(5 \%)$ containing Servalyt Precotes pH 3-10 (Serva). Focussing was carried out at $400 \mathrm{~V}$ for $4 \mathrm{~h}$. The standard test mixture with proteins of known pI included amyloglucosidase ( $\mathrm{pH} 3.5$ ), ferritin ( $\mathrm{pH} \mathrm{4.4),} \mathrm{albumin}$ ( $\mathrm{pH} \mathrm{4.7),} \beta$-lactoglobulin ( $\mathrm{pH} \mathrm{5.3),} \mathrm{conalbumin} \mathrm{(} \mathrm{pH} \mathrm{5.9),} \mathrm{horse}$ myoglobulin ( $\mathrm{pH} 7 \cdot 3$ ), whale myoglobulin ( $\mathrm{pH} 8 \cdot 3$ ), ribonuclease ( $\mathrm{pH} 9 \cdot 45)$ and cytochrome $\mathrm{c}(\mathrm{pH} \mathrm{10.65)}$.

Determination of the reaction products. The sugars produced through oxidation of different polyols by GDH were identified using HPLC. To produce the sugars for product analysis, enzyme reactions were performed in a volume of $500 \mu \mathrm{l}$. The reaction mixture contained the following components : $100 \mathrm{mM}$ Tris $/ \mathrm{HCl}$ ( $\mathrm{pH} 8.5$ ), $9 \mathrm{mg}$ polyol, $10 \mathrm{mg}$ sodium pyruvate, $1.4 \mu \mathrm{mol} N A D, 5 \mathrm{U}$ lactate dehydrogenase, and $0.22 \mathrm{U} \mathrm{GDH}$. After incubation at $28{ }^{\circ} \mathrm{C}$ for $24 \mathrm{~h}$, the sugar produced was identified by ligand exchange chromatography with HPLC on a $\mathrm{Ca}^{2+}$-loaded cation exchange matrix (Carbohydrate $\mathrm{Ca}^{2+}$, $300 \times 7 \cdot 8, \mathrm{BC}-100$, Benson). The column temperature was $85^{\circ} \mathrm{C}$. Water was used as mobile phase with a flow rate of $0.8 \mathrm{ml} \mathrm{min}^{-1}$. Detection was performed at $35^{\circ} \mathrm{C}$ with a refractive index detector (Beckman). The observed retention times were compared with those for authentic sugars, which were $14.6 \mathrm{~min}$ for galactitol, $14.8 \mathrm{~min}$ for xylitol, $8.5 \mathrm{~min}$ for xylose, $8.6 \mathrm{~min}$ for galactose, $9.8 \mathrm{~min}$ for xylulose and $11.6 \mathrm{~min}$ for tagatose.

Chemicals and enzymes. Coenzymes, enzymes and molecular mass standards were purchased from Boehringer Mannheim. Sugars, polyols, diols and alcohols were obtained from Serva or Fluka. Phenyl-Sepharose, Q-Sepharose, Sephacryl S 300 and Mono-Q were from Pharmacia, and Matrex Gel Red A from Amicon.

\section{RESULTS}

\section{Selection of a galactitol utilizing mutant of R. sphaeroides Si4}

R. sphaeroides Si4 is capable of utilizing the five polyols Dglucitol (sorbitol), D-mannitol, D-arabitol, xylitol and ribitol as carbon source, but cannot grow on galactitol (Schneider \& Giffhorn, 1989). To select a galactitolutilizing mutant, an experimental design was chosen that comprises two distinct features: the simultaneous presence of a utilizable and a non-utilizable substrate, and the absence of a mutagen. Selection was performed in a chemostat, with the concentration of the utilizable substrate D-glucitol at $1 \mathrm{mM}$ and the non-utilizable galactitol

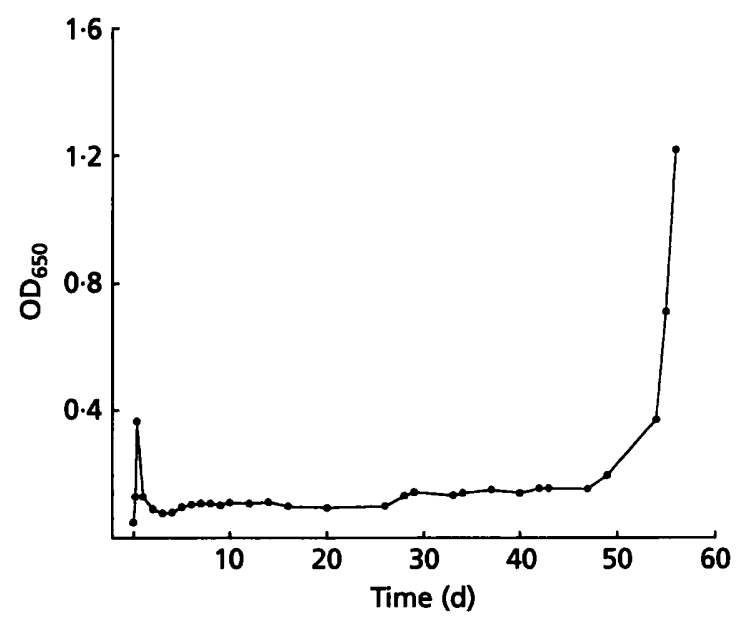

Fig. 1. Growth of $R$. sphaeroides Si4 in a chemostat with $1 \mathrm{mM}$ D-glucitol and $20 \mathrm{mM}$ galactitol. Cultivation was performed in a 2 I bioreactor with a constant working volume of 1 I at $30^{\circ} \mathrm{C}$, with aeration $\left(1 \mathrm{~min}^{-1}\right.$ ) and agitation (200 r.p.m.). The dilution rate was adjusted to $0.05 \mathrm{~h}^{-1}$. In samples taken from the bioreactor, $\mathrm{OD}_{650}$ was monitored.

at $20 \mathrm{mM}$. The continuous cultivation was carried out in a 21 bioreactor with a constant working volume of 11 at a dilution rate of $0.05 \mathrm{~h}^{-1}$. The development of the $\mathrm{OD}_{650}$ in the chemostat culture is shown in Fig. 1. After $48 \mathrm{~d}$ of growth, a significant increase in $\mathrm{OD}_{650}$ appeared, indicating the emergence of a mutant that had acquired the ability to utilize galactitol. When the culture had reached an $\mathrm{OD}_{650}$ of $1 \cdot 2$, the cultivation was continued for another $5 \mathrm{~d}$ with $1 \mathrm{mM}$ galactitol as sole carbon source. Then cells from the chemostat were plated on galactitol mineral medium (see Methods) and incubated under aerobic conditions. After repeated plating on the same medium, a single colony was isolated and subcultured in the corresponding liquid medium. The galactitol-utilizing mutant thus obtained was designated R. sphaeroides strain D. It grew with a rate of $0 \cdot 11 \mathrm{~h}^{-1}$ on galactitol, much lower than the wild-type strain on D-glucitol $\left(0.24 \mathrm{~h}^{-1}\right)$ (Schneider \& Giffhorn, 1989). Like the wild-type strain, the mutant also grew anaerobically in the light and was able to utilize each of the polyols D-glucitol, D-mannitol, D-arabitol, ribitol and xylitol for growth.

\section{Detection of a new GDH activity in cell extracts of R. sphaeroides D}

Batch cultures of R. sphaeroides Si4 and strain D were grown in minimal medium with different polyols and DLmalate as carbon source, respectively. From these cultures, cell extracts were prepared and the specific polyol dehydrogenase activities were determined (Table 1). During growth of the wild-type strain $\mathrm{Si4}$ on either Dglucitol, D-mannitol or D-arabitol, both MDH (Schneider \& Giffhorn, 1989) and SDH (Schauder et al., 1995) are expressed, resulting in enzyme activities with all three polyols. For growth on xylitol as well as ribitol, the RDH which oxidizes ribitol and xylitol (Kahle et al., 1992) is 
Table 1. Polyol dehydrogenase activities in cell extracts of $R$. sphaeroides Si4 (a) and $R$. sphaeroides $D(b)$ after growth in minimal medium with different carbon sources

Enzyme activities given represent mean values of duplicate determinations. The assays were performed in the standard assay system at $\mathrm{pH} 9 \cdot 0$. The concentrations of the polyols were $100 \mathrm{mM}$, except galactitol $(75 \mathrm{mM})$.

\begin{tabular}{|lcccccc|}
\hline Carbon source & \multicolumn{5}{c|}{ Specific activity [mU $\mathbf{~ m g}^{-\mathbf{1}}$ ] with: } \\
\cline { 2 - 7 } & Galactitol & D-Glucitol & D-Mannitol & D-Arabitol & Xylitol & Ribitol \\
\hline (a) & & & & & \\
D-Glucitol & 31 & 590 & 250 & 680 & 42 & 25 \\
D-Mannitol & 34 & 362 & 197 & 463 & 40 & 29 \\
D-Arabitol & 51 & 430 & 279 & 602 & 75 & 18 \\
D-Ribitol & 41 & 590 & 280 & 820 & 350 & 1120 \\
Xylitol & 38 & 640 & 295 & 870 & 280 & 920 \\
DL-Malate & 9 & 9 & 5 & 17 & 3 & 6 \\
(b) & & & & & & \\
Galactitol & 380 & 250 & 50 & 350 & 1780 & 5 \\
DL-Malate & 300 & 30 & 20 & 230 & 1800 & 0 \\
\hline
\end{tabular}

Table 2. Purification of GDH from $R$. sphaeroides D

\begin{tabular}{|c|c|c|c|c|c|}
\hline Fraction & $\begin{array}{c}\text { Total } \\
\text { activity } \\
\text { (U) }\end{array}$ & $\begin{array}{c}\text { Total } \\
\text { protein } \\
\text { (mg) }\end{array}$ & $\begin{array}{c}\text { Specific } \\
\text { activity } \\
\left(\mathrm{U} \mathrm{mg}^{-1}\right)\end{array}$ & $\begin{array}{c}\text { Purification } \\
\text { (-fold) }\end{array}$ & Yield (\%) \\
\hline Crude extract & 1500 & 3587 & $0 \cdot 4$ & $1 \cdot 0$ & 100 \\
\hline Ammonium sulfate precipitation & 1290 & 2692 & 0.5 & $1 \cdot 3$ & 86 \\
\hline Chromatography on Phenyl Sepharose & 1017 & 581 & $1 \cdot 8$ & $4 \cdot 5$ & 68 \\
\hline Chromatography on Q-Sepharose & 917 & 297 & $3 \cdot 0$ & $7 \cdot 5$ & 61 \\
\hline Chromatography on Matrex Gel Red-A & 653 & 126 & $5 \cdot 2$ & 13 & 44 \\
\hline Gelfiltration on Superdex 200 & 540 & 104 & $5 \cdot 2$ & 13 & 36 \\
\hline
\end{tabular}

also expressed. All three polyol dehydrogenases are suppressed during growth on malate. After growth on any of the polyols, only low GDH activities, caused by a minor activity of SDH (Schauder et al., 1995), can be detected.

In cell extracts of $\mathrm{R}$. sphaeroides $\mathrm{D}$ grown on galactitol, GDH activity was found which is at least $7 \cdot 5$-fold higher than in extracts of Si4 grown on any polyol (Table 1). In addition, the xylitol dehydrogenase activity was very high, while the specific activities for the other polyols were lower compared to $\mathrm{Si} 4$ grown on any of the polyols. Unlike the wild-type, almost the same galactitol and xylitol dehydrogenase activities have been measured in $R$. sphaeroides $\mathrm{D}$ after growth on DL-malate, indicating that these activities are expressed constitutively. These results demonstrate that the adaptation to growth on galactitol resulted in an alteration of enzymes. However, from these experiments it could not be deduced whether the properties of one of the three polyol dehydrogenases had changed or an additional polyol dehydrogenase had evolved. Therefore, the new GDH had to be isolated and studied in detail.

\section{Purification of GDH from $R$. sphaeroides D}

To obtain sufficient cell material for enzyme purification R. sphaeroides $\mathrm{D}$ was grown in a $10 \mathrm{I}$ bioreactor on minimal medium with DL-malate as carbon source. The growth rate was $0.29 \mathrm{~h}^{-1}\left(t_{\mathrm{d}}=2.4 \mathrm{~h}\right)$. At the transition to stationary phase, cells were harvested. A yield in dry mass of $1.5 \mathrm{~g} \mathrm{l}^{-1}$ was obtained. Enzyme purification was started from $61 \mathrm{~g}$ wet cells. Details of the purification procedure are described in Methods and the results are summarized in Table 2. Accordingly, GDH was purified 13-fold to a specific activity of $5 \cdot 2 \mathrm{U} \mathrm{mg}^{-1}$ with a recovery of $36 \%$. This final enzyme preparation was apparently homogeneous as shown by analytical PAGE and SDS-PAGE, each showing one single protein band (Fig. 2a, b).

\section{Properties of GDH}

SDS-PAGE of purified GDH resulted in one single protein band whose mobility corresponded to a $M_{\mathrm{r}}$ of 28000 (Fig. 2b). The molecular mass of the native enzyme was determined by sucrose gradient centrifugation $(6-30 \%, w / v$, sucrose) at $140000 \mathrm{~g}$ for $5 \mathrm{~h}$ with aldolase, 

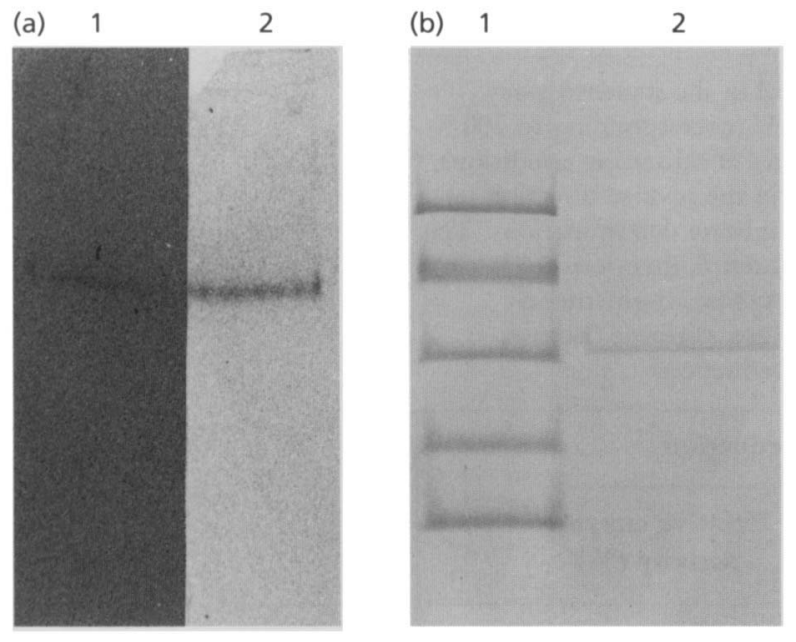

Fig. 2. PAGE of isolated GDH from $R$. sphaeroides D. (a) Analytical PAGE with an enzyme sample of the final purification step; 1 , activity stain; 2, silver stain. (b) SDS-PAGE with purified GDH (lane 2) and marker proteins (lane 1). The marker proteins are (from top to bottom): glutamate dehydrogenase $\left(M_{\mathrm{r}}=55562\right)$, aldolase (39200), triosephosphate isomerase (26000), trypsin inhibitor (20100) and lysozyme (14300).

ovalbumin and bovine serum albumin as standards (Schachmann, 1959), as well as by linear gradient PAGE (4-20\%) (Anderson et al., 1972). With both methods a $M_{\mathrm{r}}$ of $110000 \pm 5000$ was determined, demonstrating that GDH is a tetramer of identical subunits. The isolelectric point of GDH was determined to be $\mathrm{pH} 4 \cdot 2$ by isoelectric focussing.

With respect to the coenzyme, GDH was specific for $\mathrm{NAD}^{+}$. Table 3 shows the relative enzyme activities against various polyols, alcohols and sugars. GDH is very unspecific for oxidation of substrates. Galactitol is not the main substrate of GDH, the enzyme activities for the sugar alcohols xylitol and D-threitol being more than fourfold higher. In addition to sugar alcohols, several diols and secondary alcohols are substrates of this enzyme. In the reduction reaction, besides some ketoses, several carbonyl compounds are converted by GDH.

The reaction rates were determined in the standard assay systems at $\mathrm{pH} 9.0$ (oxidation) and $\mathrm{pH} 6.5$ (reduction). The saturation curves for all substrates tested were hyperbolic, and the corresponding double-reciprocal plots were linear. The apparent $K_{\mathrm{m}}$ values determined for galactitol, D-threitol, 1,2-hexandiol and $\mathrm{NAD}^{+}$(in the presence of $100 \mathrm{mM} \mathrm{1,2-hexandiol)} \mathrm{were} 240 \mathrm{mM}, 85 \mathrm{mM}, 0.2 \mathrm{mM}$ and $12 \mu \mathrm{M}$, respectively. The $K_{\mathrm{m}}$ values for acetoin, $\mathrm{L}-$ erythrulose, dihydroxyacetone, and $\mathrm{NADH}$ (in the presence of $300 \mathrm{mM}$ acetoin) were $62 \mathrm{mM}, 144 \mathrm{mM}, 48 \mathrm{mM}$ and $4 \mu \mathrm{M}$, respectively.

The products of galactitol and xylitol oxidation with GDH were identified by HPLC to be tagatose and xylulose, respectively. The configuration of the reaction products (D- or L-sugar) was determined by measuring their rotation angle in a Perkin-Elmer polarimeter. The product of enzymic galactitol oxidation was identified to be L-tagatose $\left([\alpha]_{\mathrm{D}}^{20}=5.7^{\circ}\right)$ and of xylitol oxidation to be L-xylulose $\left([\alpha]_{\mathrm{D}}^{20}=32 \cdot 2^{\circ}\right)$.

The optimal $\mathrm{pH}$ for 1,2-hexanediol oxidation by GDH was $\mathrm{pH} 10.5$ as determined in $100 \mathrm{mM}$ potassium phosphate buffer. For the reduction of acetoin, GDH activity increased with decreasing $\mathrm{pH}$ to $\mathrm{pH} 4 \cdot 0$. At lower $\mathrm{pH}$ values, NADH decayed quickly. Because of the limited stability of GDH and $\mathrm{NADH}$ at extreme $\mathrm{pH}$ values, enzyme assays were routinely performed at $\mathrm{pH} 9.0$ (oxidation) and $\mathrm{pH} 6.5$ (reduction), where GDH exhibited 81 and $63 \%$ of the activity measured at $\mathrm{pH} 10.5$ and 4.0 , respectively.

GDH activity was clearly dependent on the presence of divalent cations. When GDH solution was dialysed for 24 h against $20 \mathrm{mM}$ potassium phosphate buffer ( $\mathrm{pH} \mathrm{6.5),}$ only $44 \%$ of the initial activity was left. The addition of $1 \mathrm{mM} \mathrm{MgCl}, \mathrm{MnCl}_{2}, \mathrm{NiCl}_{2}$ or $\mathrm{CoCl}_{2}$ restored 99, 101, 125 and $121 \%$ of the initial GDH activity, respectively. $\mathrm{ZnSO}_{4}$ and $\mathrm{FeSO}_{4}$ were inhibitory to the enzyme. When added at a concentration of $1 \mathrm{mM}$, the chelating agents EDTA and $\alpha, \alpha^{\prime}$-dipyridyl reduced GDH activity to 32 and $87 \%$, respectively, and the inactivation could be completely reversed by the addition of $2 \mathrm{mM} \mathrm{MgCl}_{2}$. The sulfhydryl group modifying reagents iodoacetamide, iodoacetic acid, DTT and arsenic acid had no inhibitory effect on GDH at a concentration of $1 \mathrm{mM}$, but $1 \mathrm{mM}$ bromosuccinimide inhibited GDH completely.

The stability of GDH was tested in $20 \mathrm{mM}$ Bistris buffer $(\mathrm{pH} 6.5+1 \mathrm{mM} \mathrm{MgCl})_{2}$ in the presence and absence of $30 \%$ sucrose. After incubation for 3 months at $4{ }^{\circ} \mathrm{C}$ with and without sucrose, 100 and $85 \%$ of the initial enzyme activity remained. Accordingly, GDH is stabilized by sucrose. Thermal stability of the enzyme was investigated in the optimal buffer $(20 \mathrm{mM}$ Bistris, $\mathrm{pH} 6.5+1 \mathrm{mM}$ $\mathrm{MgCl}_{2}+30 \%$ sucrose). The enzyme lost $50 \%$ of the initial activity during incubation at $28,37,40,45$ and $50^{\circ} \mathrm{C}$ after $70 \mathrm{~d}, 8 \mathrm{~d}, 5 \mathrm{~d}, 10 \mathrm{~h}$ and $12 \mathrm{~min}$, respectively.

\section{Comparison of GDH with the other polyol dehydrogenases from $R$. sphaeroides}

On the basis of its biochemical and kinetic properties, GDH is clearly different to all three polyol dehydrogenases from R. sphaeroides Si4 (Table 4). The amino acid sequence of $\mathrm{MDH}$ has already been determined (Schneider et al., 1993). RDH (Kahle et al., 1992) and SDH (Schauder et al., 1995) from R. sphaeroides Si4 as well as GDH from $R$. sphaeroides $\mathrm{D}$ were isolated and subjected to a partial amino acid sequence analysis starting from the $\mathrm{N}$ terminus by automated sequencing with a $473 \mathrm{~A}$ sequencer from Applied Biosystems. The comparative amino acid sequences show (Fig. 3) that although GDH and the other polyol dehydrogenases are not homologous, there is a significant sequence identity between $\mathrm{GDH}, \mathrm{SDH}$ and $\mathrm{MDH}$. However, there is apparently no identity between any of these enzymes and RDH. 


\section{Table 3. Substrate specificity of GDH from $R$. sphaeroides D}

Enzyme activities in the direction of oxidation and reduction were measured in the standard assay systems at $\mathrm{pH} 9.0$ and $\mathrm{pH} 6.5$, respectively. The assays each contained $0.05 \mathrm{U}$ (corresponding to $100 \%$ with galactitol or L-tagatose as substrate) of purified GDH and the substrates at saturating conditions. These were $100 \mathrm{mM}$ for substrate oxidation except galactitol $(75 \mathrm{mM})$ and in the reverse direction $200 \mathrm{mM}$ except lactose $(50 \mathrm{mM})$. The activities given are mean values of duplicate determinations. The following compounds were not substrates for GDH: ribitol, L-arabitol, L-threitol, myo-inositol, ethylene glycol, $n$-butanol, ethanol and methanol (substrate oxidation); D-fructose, D-glucose, Dmannose, D-galactose, L-sorbose, D-arabinose, L-arabinose, L-ribulose, D-xylose, D-ribose, lactose, melobiose, maltose, raffinose, furanose, 2-butanone and acetone (substrate reduction)

\begin{tabular}{|c|c|c|c|}
\hline \multicolumn{2}{|c|}{ Substrate oxidation } & \multicolumn{2}{|c|}{ Substrate reduction } \\
\hline Substrate & $\begin{array}{l}\text { Relative enzyme } \\
\text { activity }(\%)\end{array}$ & Substrate & $\begin{array}{c}\text { Relative enzyme } \\
\text { activity (\%) }\end{array}$ \\
\hline Galactitol & 100 & L-Tagatose & 100 \\
\hline D-Glucitol & 6 & D-Tagatose & 4 \\
\hline L-Glucitol & 83 & D-Ribulose & 696 \\
\hline D-Mannitol & 2 & D-Xylulose & 42 \\
\hline Xylitol & 410 & L-Erythrulose & 1183 \\
\hline D-Arabitol & 64 & Acetoin & 304 \\
\hline D-Threitol & 428 & L-Glyceraldehyde & 383 \\
\hline$m$-Erythritol & 4 & D-Glyceraldehyde & 281 \\
\hline Glycerol & 51 & Dihydroxyacetone & 281 \\
\hline 1,2-Hexanediol & 323 & & \\
\hline 2-Hexanol & 170 & & \\
\hline 1,2-Pentanediol & 269 & & \\
\hline 1,2-Butanediol & 95 & & \\
\hline$(2 \mathrm{~S}, 3 \mathrm{~S})$-Butanediol & 74 & & \\
\hline$(2 \mathrm{R}, 3 \mathrm{R})$-Butanediol & 8 & & \\
\hline (2S)-Butanol & 46 & & \\
\hline (2R)-Butanol & 24 & & \\
\hline 1,2-Propanediol & 71 & & \\
\hline 2-Propanol & 42 & & \\
\hline
\end{tabular}

Table 4. Properties of polyol dehydrogenases from $R$. sphaeroides

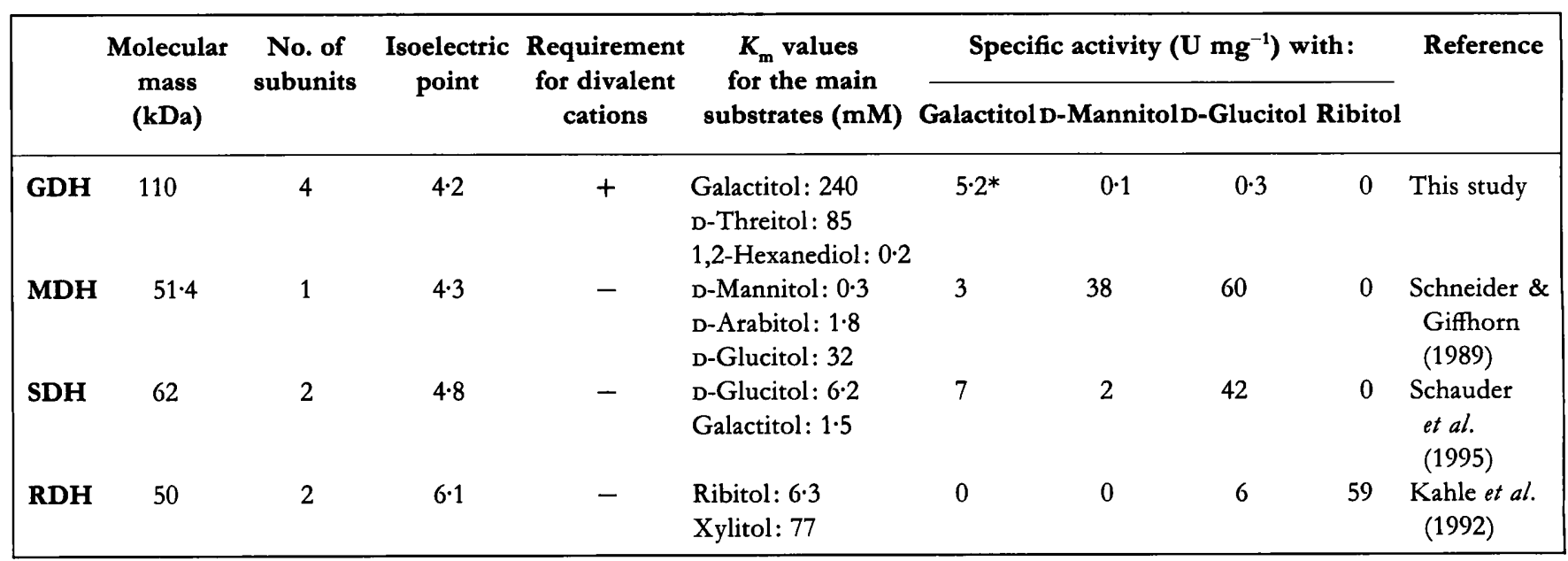

* Due to the low solubility of galactitol in aqueous solution (about $33.3 \mathrm{~g} \mathrm{l}^{-1}$ ) the activity was assayed under non-saturating conditions (see Methods). 


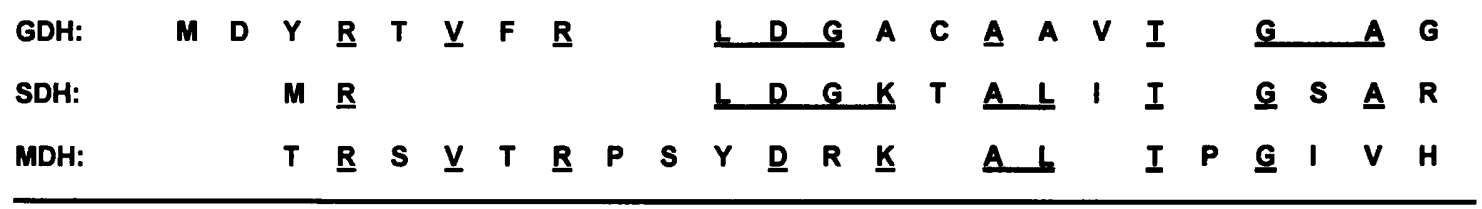

RDH: $\quad$ A $E$ E $L$

Fig. 3. N-terminal amino acid sequences of GDH from $R$. sphaeroides D, and SDH, MDH and RDH from $R$. sphaeroides Si4.

\section{DISCUSSION}

A spontaneous gain of function mutant of $R$. sphaeroides Si4 capable of growing on the previously nonmetabolizable sugar alcohol galactitol was isolated from a chemostat culture grown under selective pressure. Unlike the parental strain, the mutant $R$. sphaeroides $\mathrm{D}$ produced elevated levels of a newly expressed GDH. The purified enzyme exhibits a number of properties different to all other polyol dehydrogenases. GDH is inactivated by dialysis or by treatment with EDTA, and its activity can be completely restored by incubation with one of the divalent cations $\mathrm{Mg}^{2+}, \mathrm{Mn}^{2+}, \mathrm{Co}^{2+}$ and $\mathrm{Ni}^{2+}$, but not in the presence of $\mathrm{Zn}^{2+}$ which has an inhibitory effect. Unlike GDH of R. sphaeroides D, most bacterial polyol dehydrogenases do not require metal ions for catalytic activity (Taylor et al., 1974; Neuberger et al., 1979; Wojtkiewicz et al., 1988; Schneider \& Giffhorn, 1989, 1991; Kahle et al., 1992; Schauder et al., 1995). SDH of Bacillus subtilis is a remarkable exception. This enzyme requires $\mathrm{Zn}^{2+}(\mathrm{Ng}$ et al., 1992) similar to mammalian SDHs (Jeffery \& Jörnvall, 1988; Jeffery et al., 1984). Another striking characteristic of the $R$. sphaeroides $\mathrm{D}$ GDH is its unusual substrate profile. Unlike all other polyol dehydrogenases, GDH oxidizes aliphatic diols and secondary aliphatic alcohols in addition to different sugar alcohols. It is evident that the preferred substrates of this enzyme are aliphatic diols $\left(K_{\mathrm{m}}\right.$ for 1,2-hexanediol $=$ $0.2 \mathrm{mM})$ rather than the sugar alcohols $\left(K_{\mathrm{m}}\right.$ for galactitol $=240 \mathrm{mM}$ ). These findings do not only pose the question of how GDH has originated, but also open up interesting perspectives for biotechnical applications of this biocatalyst. The enzymic synthesis of the rare sugar Ltagatose by regioselective oxidation of galactitol at C-5 with GDH has been demonstrated and bioconversions according to previous studies are currently being elaborated (Schwartz et al., 1994). Further, it has been shown that GDH oxidizes the secondary alcohols (2S)butanol and $(2 S, 3 S)$-butanediol with relatively high rates, but not primary alcohols. Therefore, it is most likely that the aliphatic diols 1,2-propanediol, 1,2-butanediol, 1,2pentanediol and 1,2-hexanediol are oxidized at C-2 to yield the corresponding keto-alcohol, indicating a possible application of the enzyme for enantioselective reduction of various keto-alcohols (Keinan et al., 1986).

Apparently, the acquisition of the new metabolic capa- bility by R. sphaeroides Si4 occurred by derepression of a new GDH, and is not caused by the galactitol side activity of overproduced MDH (Schneider \& Giffhorn, 1989) or SDH (Schauder et al., 1995) as initially expected. In this respect, galactitol metabolism of $\mathrm{R}$. sphaeroides $\mathrm{Si4}$ is different from the acquired xylitol metabolism of Klebsiella aerogenes which utilizes xylitol by means of a side activity of an overproduced RDH (Wu et al., 1968; Hartley et al., 1972; Rigby et al., 1974). Rather, galactitol metabolism is similar to acquisitive growth of $R$. sphaeroides on hexoses or $\mathbf{D}$-(-)-tartrate as the result of derepression of a previously unrecognized gluconate-6-phosphate dehydratase (Szymona \& Doudoroff, 1960) and D- $(-)$ tartrate dehydratase (Rode \& Giffhorn, 1982, 1983), respectively. Although utilization of some primary aliphatic alcohols by strains of $R$. sphaeroides has been reported (Kondratieva, 1979), substantial studies on the enzymes involved in the oxidation of these substrates are lacking. This study shows that GDH of the R. sphaeroides mutant D is different to MDH (Schneider \& Giffhorn, 1989), RDH (Kahle et al., 1992) and SDH (Schauder et al., 1995) of the wild-type strain. These differences refer to size of the native enzyme, its subunit composition, metal requirement, and substrate specificity (Table 4 ). On the other hand, the $\mathrm{N}$-terminal amino acid sequences of GDH, SDH and MDH (Fig. 3) show a significant identity among these enzymes, supporting the idea that they may have evolved from a common ancestor protein. However, it is rather unlikely that GDH has evolved from SDH or $\mathrm{MDH}$ during the course of continuous cultivation under selective pressure. Most likely a cryptic gene has been activated. Cryptic genes are phenotypically silent DNA sequences not normally expressed during the life cycle of a bacterial culture (Hall et al., 1983). However, when a culture is exposed to selective pressure during a prolonged time, mutants with new metabolic functions can develop (Hall et al., 1983; Parker et al., 1988). To elucidate the origin of GDH, its true function and its relationship to MDH (Schneider et al., 1993), SDH and other polyol dehydrogenases (Schauder $e$ t al., 1995), we will isolate and sequence the structural gene encoding this enzyme.

\section{ACKNOWLEDGEMENTS}

We thank Stephan Schauder for providing isolated SDH for amino acid sequencing. This study was supported by grant $\mathrm{Gi}$ $147 / 2-1$ of the Deutsche Forschungsgemeinschaft. 


\section{REFERENCES}

Anderson, L. O., Borg, H. \& Michaelson, M. (1972). Molecular weight estimations of proteins by electrophoresis in polyacrylamide gels of graded porosity. FEBS Lett 20, 199-202.

Buchholz, S. E., O'Mullan, P. \& Eveleigh, D. E. (1988). Growth of Zymomonas mobilis CP4 on mannitol. Appl Microbiol Biotechnol 29, 275-281.

Chen, Y. M., Chakrabarti, T. \& Lin, E. C. C. (1984). Constitutive activation of $\mathrm{L}$-fucose genes by an unlinked mutation in E. coli. $J$ Bacteriol 159, 725-729.

Davis, B. J. (1964). Disk electrophoresis. II. Method and application to human serum protein. Ann NY Acad Sci 121, 404-423.

Doten, R. C. \& Mortlock, R. P. (1984). Directed evolution of a second xylitol catabolic pathway in Klebsiella pneumoniae. J Bacteriol 159, 730-735.

Drueckhammer, D. G., Hennen, W. J., Pederson, R. L., Barbas, C. F., Gautheron, C. M., Krach, T. \& Wong, C. H. (1991). Enzyme catalysis in synthetic carbohydrate chemistry. Syntbesis 7, 499-525.

Dykhuizen, D. E. \& Hartl, D. L. (1983). Selection in chemostats. Microbiol Rev 47, 150-168.

Goa, J. (1953). A micro Biuret method for protein determination. Scand J Clin Invest 5, 218-222.

Hall, B. G. (1981). Changes in the substrate specificities of an enzyme during directed evolution of new functions. Biochemistry 20 , 4042-4049.

Hall, B. G., Yokoyama, S. \& Calhoun, D. H. (1983). Role of cryptic genes in microbial evolution. Mol Biol Evol 1, 109-124.

Hartley, B. S., Burleigh, B. D., Midwinter, G. G., Moore, C. H., Morris, H. R., Rigby, P. W. J., Smith, M. J. \& Taylor, S. S. (1972). Where do enzymes come from? FEBS Lett 29, 151-176.

Hegeman, G. D. \& Rosenberg, S. L. (1970). The evolution of bacterial enzyme systems. Annu Rev Microbiol 24, 429-462.

Jeffery, J. \& Jörnvall, H. (1988). Sorbitol dehydrogenase. $A d v$ Enzymol Relat Areas Mol Biol 61, 47-106.

Jeffery, J., Chesters, J., Mills, C., Sadler, P. J. \& Jörnvall, H. (1984). Sorbitol dehydrogenase is a zinc enzyme. EMBO J 3, 357-360.

Kahle, C., Schneider, K. H. \& Giffhorn, F. (1992). Pentitol metabolism of $\mathrm{R}$ hodobacter spbaeroides $\mathrm{Si4}$ : purification and characterization of a ribitol dehydrogenase. $J$ Gen Microbiol 138, 1277-1281.

Keinan, E., Hafeli, E. K., Seth, K. K. \& Lamed, R. (1986). Thermostable enzymes in organic synthesis. 2. Asymmetric reduction of ketones with alcohol dehydrogenase from Thermoanaerobium brockii. I Am Chem Soc 108, 162-169.

Kondratieva, E. N. (1979). Interrelation between modes of carbon assimilation and energy production in phototrophic purple and green bacteria. Int Rev Biochem 21, 117-175.

Kyslik, P. \& Dobisova, M. (1986). Selection of ribitol dehydrogenase hyperproducing strains in a chemostat culture of Escherichia coli 1EA at different dilution rates. Biotechnol Lett 8, 235-240.

Laemmli, U. K. (1970). Cleavage of structural proteins during the assembly of the head of bacteriophage T4. Nature 227, 680-685.

Lambert, T., Ploy, M. C. \& Courvalin, P. (1994). A spontaneous point mutation in the $a a c\left(6^{\prime}\right)-I b^{\prime}$ gene results in altered substrate specificity of aminoglycoside $6^{\prime}-N$-acetyltransferase of a Pseudomonas fluorescens strain. FEMS Microbiol Lett 115, 297-304.

LeBlanc, D. J. \& Mortlock, R. P. (1971). Metabolism of D-arabinose: a new pathway in Escherichia coli. J Bacteriol 106, 90-96.

Lerner, S. A., Wu, T. T. \& Lin, E. C. C. (1964). Evolution of a catabolic pathway in bacteria. Science 146, 1313-1315.
Mayers-Kuntzer, H., Reichert, A., Schneider, K. H. \& Giffhorn, F. (1994). Isolation and characterization of a L-glucitol dehydrogenase from the newly isolated bacterium Pseudomonas sp. Ac. $J$ Biotechnol 36, 157-164.

Merril, C. R., Goldman, D., Sedman, S. A. \& Ebert, M. H. (1981). Ultrasensitive stain for proteins in polyacrylamide gels shows regional variations in cerebrospinal fluid proteins. Science 211, 1437-1438.

Neuberger, M. S., Patterson, R. A. \& Hartley, B. S. (1979). Purification and properties of Klebsiella aerogenes $\mathrm{D}$-arabitol dehydrogenase. Biocbem J 183, 31-42.

Ng, K., Ye, R., Wu, X.C. \& Wong, S.L. (1992). Sorbitol dehydrogenase from Bacillus subtilis - purification, characterization and gene cloning. $J$ Biol Chem 267, 24989-24994.

Parker, L. L., Betts, P. W. \& Hall, B. G. (1988). Activation of a cryptic gene by excision of a DNA fragment. $J$ Bacteriol 170, 218-222.

Pfennig, N. \& Lippert, K. D. (1966). Über das Vitamin B 12Bedürfnis phototropher Schwefelbakterien. Arch Microbiol 55, 245-256.

Rigby, P. W. J., Burleigh, B. D., Jr \& Hartley, B. S. (1974). Gene duplication in experimental enzyme evolution. Nature 251, 200-204.

Rode, H. \& Giffhorn, F. (1982). D-(-)-Tartrate dehydratase of Rhodopseudomonas sphaeroides: purification, characterization and application to enzymatic determination of $\mathrm{D}-(-)$-tartrate. $J$ Bacteriol 150, 1061-1068.

Rode, H. \& Giffhorn, F. (1983). Adaptation of Rbodopseudomonas sphaeroides to growth on $\mathrm{D}-(-)$-tartrate and large-scale production of constitutive $\mathrm{D}-(-)$-tartrate-dehydratase during growth on DLmalate. Appl Environ Microbiol 45, 716-719.

Schachmann, H. K. (1959). Ultracentrifugation in Biochemistry. New York: Academic Press.

Schauder, S., Schneider, K. H. \& Giffhorn, F. (1995). Polyol metabolism of Rhodobacter sphaeroides: biochemical characterization of a short-chain sorbitol dehydrogenase. Microbiology 141, 1857-1863.

Schneider, K. H. \& Giffhorn, F. (1989). Purification and properties of a polyol dehydrogenase from the phototrophic bacterium Rbodobacter sphaeroides. Eur J Biocbem 184, 15-19.

Schneider, K. H. \& Giffhorn, F. (1991). Sorbitol dehydrogenase from $P$ seudomonas sp.: purification, characterization and application to quantitative determination of sorbitol. Enzyme Microb Tecbnol 13, 332-337.

Schneider, K. H., Giffhorn, F. \& Kaplan, S. (1993). Cloning, nucleotide sequence and characterization of the mannitol dehydrogenase gene from Rbodobacter spbaeroides. J Gen Microbiol 139, 2475-2484.

Schwartz, D., Stein, M., Schneider, K. H. \& Giffhorn, F. (1994). Synthesis of $\mathrm{D}$-xylulose from $\mathrm{D}$-arabitol by enzymatic conversion with immobilized mannitol dehydrogenase from Rhodobacter sphaeroides. J Biotechnol 33, 95-101.

Srinivasan, K., Konstantinidis, A., Sinnott, M. L. \& Hall, B. G. (1993). Large changes of transition-state structure during experimental evolution of an enzyme. Biochem $J$ 291, 15-17.

Szymona, M. \& Doudoroff, M. (1960). Carbohydrate metabolism in Rhodopseudomonas sphaeroides. J Gen Microbiol 22, 167-183.

Taylor, S. S., Rigby, P. W. J. \& Hartley, B. S. (1974). Ribitol dehydrogenase from Klebsiella aerogenes. Purification and subunit structure. Biochem J 141, 693-700.

Wawzonek Thompson, L. \& Krawiec, S. (1983). Acquisitive 
evolution of ribitol dehydrogenase in Klebsiella pneumoniae. J Bacteriol 154, 1027-1031.

Wojtkiewicz, B., Szmidzinski, R., Jezierska, A. \& Cocito, C. (1988). Identification of a salvage pathway for $\mathrm{D}$-arabinose in Mycobacterium smegmatis. Eur J Biochem 172, 197-203.

Wu, T. T., Lin, E. C. C. \& Tanaka, S. (1968). Mutants of Aerobacter aerogenes capable of utilizing xylitol as a novel carbon source. $J$ Bacteriol 96, 447-456.

Received 14 December 1994; revised 7 March 1995; accepted 24 March 1995. 